\title{
A review of snow manipulation experiments in Arctic and alpine tundra ecosystems
}

\author{
Sonja Wipf ${ }^{1,2} \&$ Christian Rixen $^{2}$ \\ 1 WSL Swiss Federal Institute for Forest, Snow and Landscape Research, Zürcherstr. 111, CH-8903 Birmensdorf, Switzerland \\ 2 WSL Institute for Snow and Avalanche Research SLF, Unit Ecosystem Boundaries, Alpine Ecosystems, Flüelastr. 11, CH-7260 Davos, Switzerland
}

\section{Keywords}

Meta-analysis; plant phenology; productivity; snow fence; snow removal; winter ecology.

\section{Correspondence}

Sonja Wipf, WSL Swiss Federal Institute for

Forest, Snow and Landscape Research;

Zürcherstr. 111, CH-8903 Birmensdorf,

Switzerland. E-mail: sonja.wipf@wsl.ch

doi:10.1111/j.1751-8369.2010.00153.x

\begin{abstract}
Snow cover is one of the most important factors controlling microclimate and plant growing conditions for Arctic and alpine ecosystems. Climate change is altering snowfall regimes, which in turn influences snow cover and ultimately tundra plant communities. The interest in winter climate change and the number of experiments exploring the responses of alpine and Arctic ecosystems to changes in snow cover have been growing in recent years, but their outcomes are difficult to summarize because of the large variability in manipulation approaches, extents and measured response variables. In this review, we (1) compile the ecological publications on snow manipulation experiments, (2) classify the studies according to the climate scenarios they simulate and response variables they measure, (3) discuss the methods applied to manipulate snow cover, and (4) analyse and generalize the response in phenology, productivity and community composition by means of a meta-analysis. This meta-analysis shows that flowering phenology responded strongly to changes in the timing of snowmelt. The least responsive group of species were graminoids; however, they did show a decrease in productivity and abundance with experimentally increased snow covers. The species group with the greatest phenological response to snowmelt changes were the dwarf shrubs. Their abundance also increased in most long-term snow fence experiments, whereas species richness generally declined. We conclude that snow manipulation experiments can improve our understanding of recently observed ecosystem changes, and are an important component of climate change research.
\end{abstract}

Seasonal snow cover is a characteristic feature of most Arctic and alpine regions. Generally snow covers soil and plants for more than half of the year, and during this period determines important environmental variables such as soil temperatures and freezing depth, which in turn control various ecosystem processes. The melting of the snow cover defines the start and length of the summer growing season, and water and nutrients released from the snow pack influence soil moisture and nutrient status until later in the summer. Thus, the snow cover directly and indirectly impacts ecosystems in various ways, and its influence is not restricted to the winter season.

Arctic and alpine regions are among the most affected by climatic change (Symon et al. 2005; Solomon et al. 2007). Earlier snowmelt dates, decreased snow depths and an increasing proportion of winter precipitation falling as rain instead of snow have been recorded in the Arctic (Frei et al. 1999; Brown 2000; Serreze et al. 2000) and in mountain areas (Beniston 1997; Laternser \& Schneebeli 2003; Mote et al. 2005; Marty 2008). Many Arctic and high-mountain areas have not (yet) experienced a significant change in the quantity of winter precipitation and in snow depth, but most regions are seeing an earlier melt-out resulting from warmer spring temperatures (Solomon et al. 2007). Climate change scenarios are rather vague about future snow conditions. In the future, the quantities of snow might increase in the Arctic and some continental mountain ranges because of rising levels of winter precipitation (Saha et al. 2006; Solomon et al. 2007). Lower altitudes and oceanic mountain ranges, however, might experience a decrease in the snow-to-rain ratio because of warmer winter temperatures. Regardless of the quantity of precipitation, such 
regions could face a decline in snow cover and an advance in snowmelt timing (Lapp et al. 2005; Henry 2008).

With anthropogenic climate change, interactions between snow and Arctic and alpine plants have received increasing attention in the past two decades, and have been addressed in numerous studies; however, they have not yet been analysed in a comprehensive review. The purpose of this review is to compile publications on snowmelt manipulation experiments, and to generalize their findings about how snowmelt affects plant phenology and productivity. In particular, we will compile the publications on snow manipulation experiments with a focus on plant ecological responses, and will classify these studies according to the climate scenarios they actually simulate, then discuss the methods used for the snow manipulation, and finally analyse and generalize the response in phenology and productivity by means of a meta-analysis.

\section{Scenarios and methods used in snow manipulation experiments}

Table 1 lists existing publications on snowmelt experiments and their main characteristics, such as the start and duration of the experiment, the method used, the direction and extent of the snow manipulation, the characteristics of the natural snow cover, the climate scenarios applied and the response variables measured. We limited our list and review to studies with snow manipulation treatments that were performed in Arctic and alpine tundra, that investigated plant and vegetation responses, and in which the experimental treatments were not confounded with other climate change manipulations. Thus, studies from montane and boreal forest ecosystems (e.g., Boutin \& Robitaille 1995; Groffman et al. 1999) and studies that focus on soil responses and experiments with all-summer warming treatments that start by melting the snow early (Harte et al. 1995) were not included.

In the 39 publications, 22 experiments from alpine and sub-alpine and 19 from Arctic and sub-Arctic ecosystems were described. Although most (22) publications report on experiments that had been running for 1-2 years, Smith et al. (1995) described vegetation changes caused by a snow fence over 32 years. Established in 1959, this experiment in alpine New Zealand probably holds the record for the oldest continuously running snow ecology experiment. Of the experiments reviewed, 23 delayed snowmelt, eight advanced it and eight did both. In addition to the snowmelt treatment (and not confounded with it), a warming treatment was applied in 14 experiments, mainly in Arctic ecosystems.
The snow manipulation experiments listed in Table 1 can roughly be categorized into three types, differing in the climate scenarios they actually simulate: increased snow and/or delayed snowmelt; earlier snowmelt; and earlier snowmelt combined with a summer warming treatment. Each of these three scenarios are discussed below.

\section{Increased snow and/or delayed snowmelt}

Increased winter precipitation in the form of snow is expected in most Arctic regions (Solomon et al. 2007), and also in some high-alpine regions (OcCC Consortium 2007), in future decades. With the concurrent warming trend, however, the deeper snowpack is likely to melt faster, and therefore snowmelt may not be considerably delayed. Most snow manipulation experiments that simulated increased quantities of snow have done so by accumulating wind-drifted snow, e.g., behind snow fences or within open-top chambers (OTCs). Once installed, these experiments do not require the presence of researchers over winter, which may partly explain the fact that more than half of the experiments reviewed for this paper applied this method. However, as the accumulated snow will take longer to melt, it must be carefully considered whether a postponed snowmelt date is an appropriate climate scenario for a given region. Alternatively, a spring warming treatment may be applied to speed up snowmelt (e.g., by using OTCs, as in Abisko, see below). In addition, a methodological flaw of snow fences is that they can trap wind-drifted litter in their lee (Fahnestock et al. 2000), thus increasing the nutrient influx.

\section{Earlier snowmelt}

An increased occurrence of midwinter thawing events and less winter precipitation in the form of snow (because of above-zero winter temperatures) have already become apparent in some oceanic and continental mountain regions (Rikiishi et al. 2004; Scherrer et al. 2004; Mote et al. 2005). The effects on environmental conditions that ecosystems experience are two-fold. If snow depth remains below a certain threshold (Sturm et al. 1997), soil frosts and the frequency of freeze-thaw cycles could increase and induce "colder soils in a warmer world" (Groffman et al. 2001). Moreover, a thinner snow cover will cause snow to melt more quickly, shifting the growing season towards an earlier, usually colder time of the year, unless this is compensated by a strong warming trend. In experiments, the scenario of less snow is most frequently created by either manipulating snow depths manually (i.e., shovelling away snow) or by increasing 


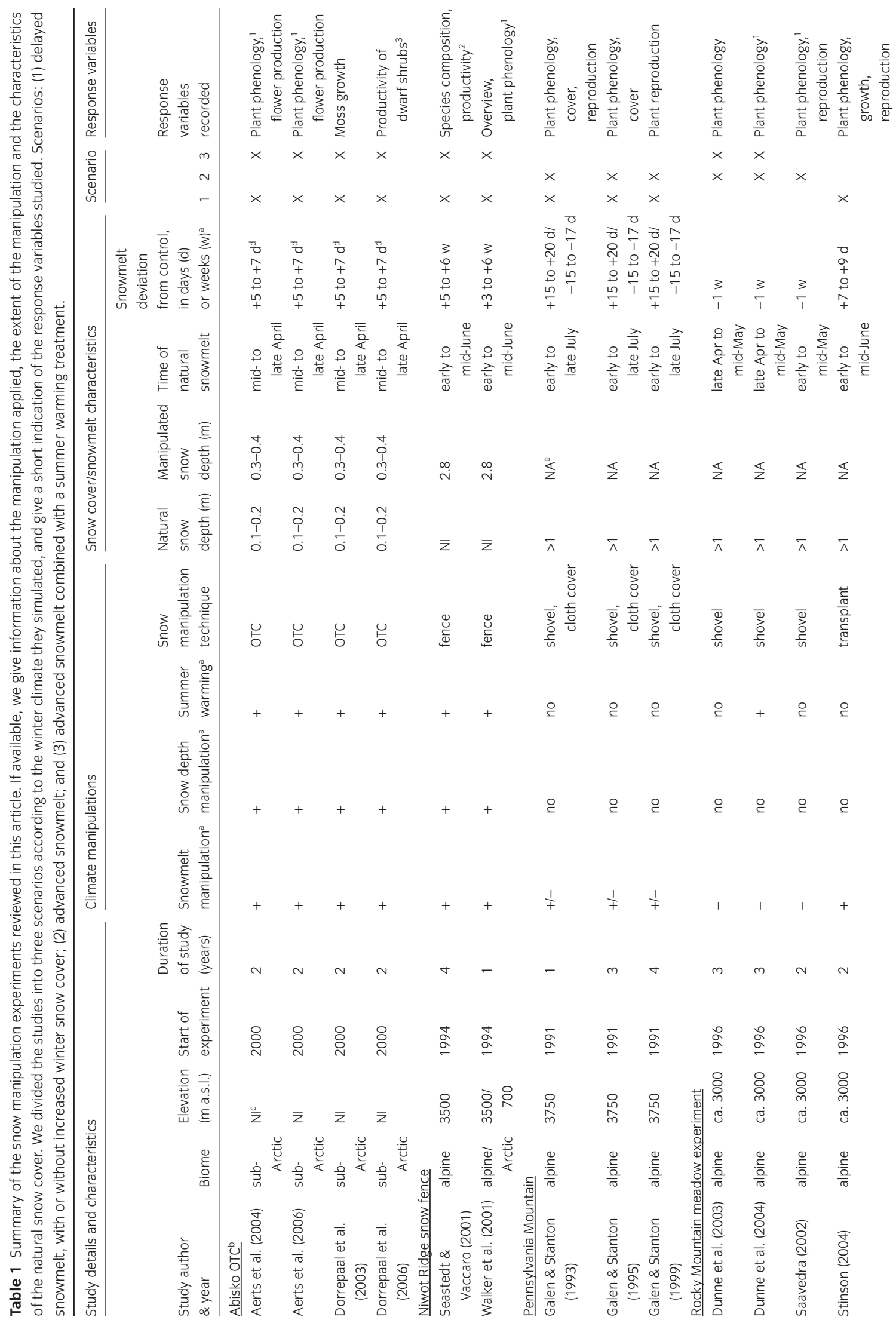




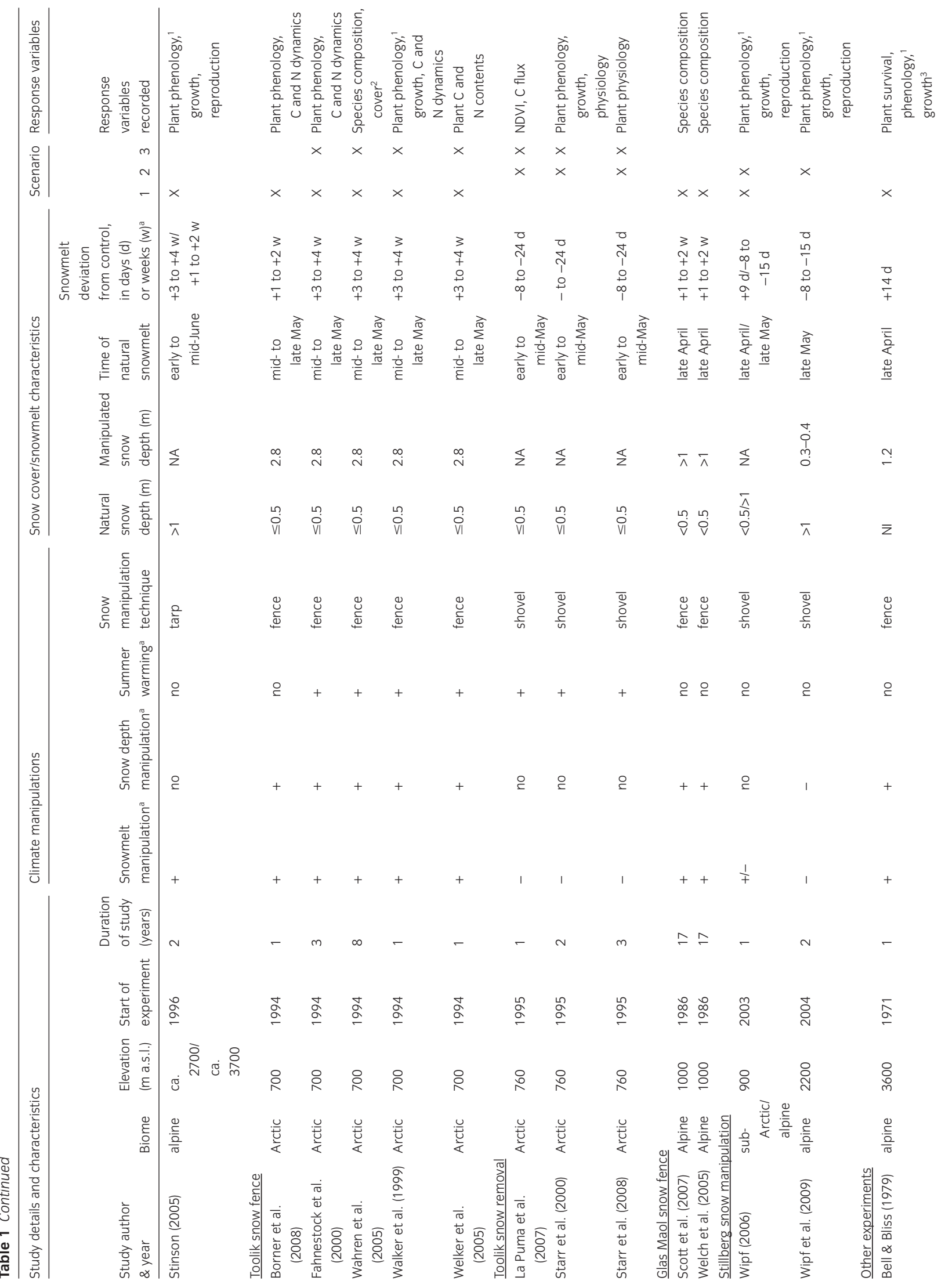



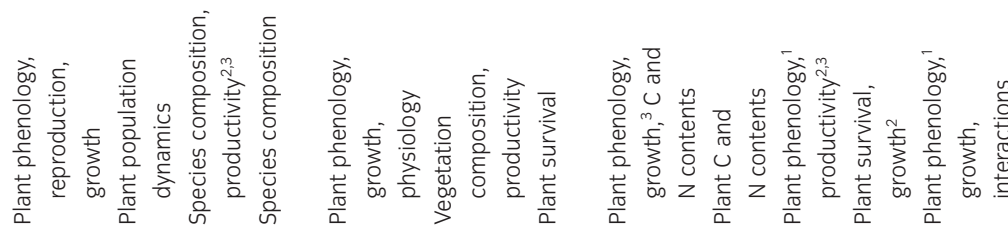

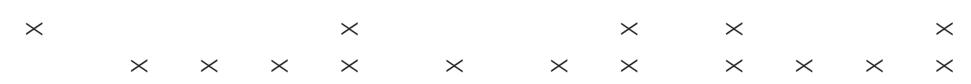

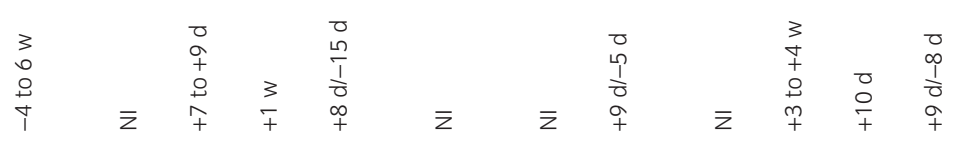

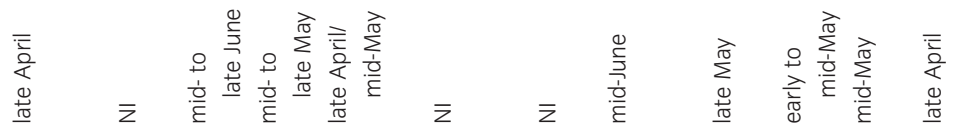

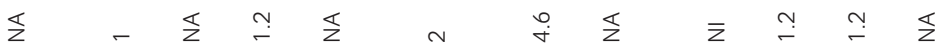

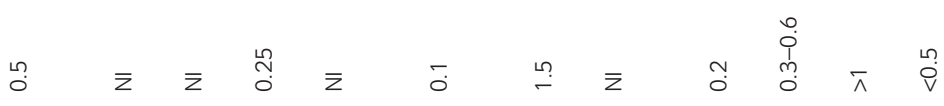

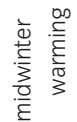

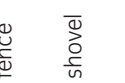

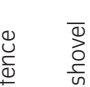

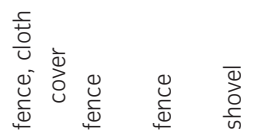

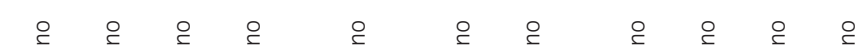

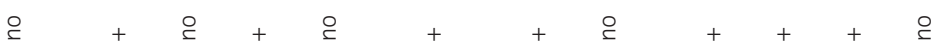

ڤે

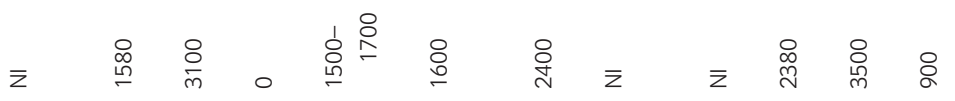

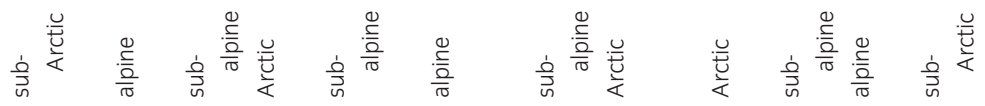

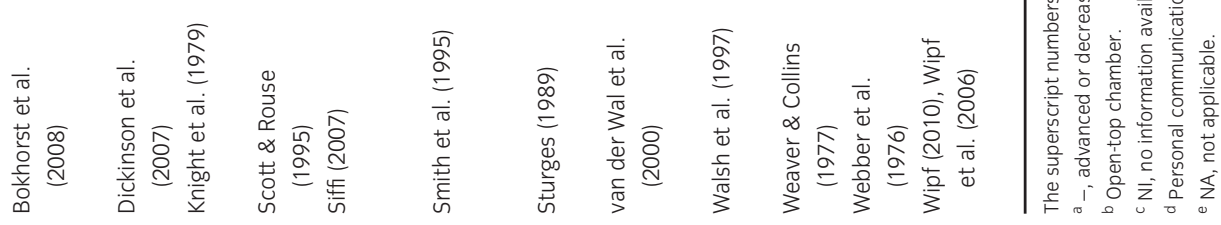


snowmelt rates (i.e., using dark cloth covers to accelerate snowmelt) in spring. In general, these two methods are the most flexible in terms of the snowmelt scenarios that can be simulated, and can also be used to delay snowmelt (by increasing snow depth or using reflective cloth covers). However, there is a risk of unwanted side effects, such as snow compaction or changes in the level of light penetrating the snowpack. Moreover, these techniques are generally labour intensive, and require the labour to be performed near natural snowmelt, which varies from year to year and cannot be predicted far in advance. Another type of experiment transplants plants and soil between sites with different snow cover characteristics. Scenarios are limited to currently existing snow regimes, which are often persistent between years (Buus-Hinkler et al. 2006; Edmonds et al. 2006). Plot sizes are usually small (below $\mathrm{l} \mathrm{m}^{2}$ ), and the transplanting poses a significant disturbance to the ecosystem. Extensive replication and the use of true controls, i.e., comparing plots transplanted between sites with those transplanted within sites, can account for these disadvantages.

\section{Earlier snowmelt combined with a summer warming treatment}

The most realistic scenario for probably most Arctic and alpine regions is the combination of experimentally advanced snowmelt and spring and summer warming. In experiments, this scenario is simulated by applying a warming treatment that starts before the snow has melted, and therefore accelerates and advances snowmelt. To date, this scenario has only been addressed in a relatively small number of studies, mostly using OTCs (Table 1). With the use of overhead infrared heaters or heating cables, such experiments are now on the increase. However, the responses to earlier snowmelt and to the subsequent warming are not quantified separately in most of these warming experiments. As we focus on snow manipulation treatments in this review, of the studies using scenario 3 we therefore only consider "true" snowmelt experiments, in which snow manipulations were conducted in addition to the warming treatment, and not confounded with it (Table 1).

\section{Meta-analysis}

To generalize the response patterns found in snow manipulation experiments, we analysed the response of target species (phenology, growth and productivity) or species groups (total productivity and vegetation composition) to snowmelt manipulation in a meta-analysis using results from subsets of the studies listed in Table 1. From data reported in texts, tables or figures, we calcu- lated the treatment effects (i.e., our response variable) as the percentage deviation from controls (Dormann $\&$ Woodin 2002). A classical meta-analysis approach, which expresses effect size as multiples of standard deviations, was not possible because too few experiments published the information necessary for these calculations. Furthermore, the number of studies did not allow testing for effects of regions, community types or duration of the experiment. However, the studies are distributed widely across regions and communities, and therefore allow generalizations. We collected a data set of 66 species and year combinations of flowering phenology and 38 of species productivity (Table 2 ). In addition, we analysed 18 cases where the response in above-ground productivity of the whole plant community was reported. For the metaanalysis of the phenology data, both results from experiments with advanced and delayed snowmelt could be used. Most experiments that reported above-ground vegetation productivity or productivity of target species had applied a snow fence approach, and thus delayed snowmelt. For the analysis of this productivity data, we therefore excluded the very few studies with advanced snowmelt to obtain a balanced design.

The flowering phenology was indicated as the average prefloration period in a plot, i.e., the time span between snowmelt and flowering. Flowering was reported as the date of peak flowering in most studies, but in some cases was reported as the date flower buds opened or the date of the appearance of the first flower. Productivity was based on measures of biomass production, but in the cases of some dwarf shrubs it was given as stem elongation or as the dry mass of leaves produced in a year.

We tested with general linear models (glms) whether the response variables were affected by species characteristics (e.g., functional group, sensu Chapin et al. [1994], or flowering timing), and by characteristics of the snow cover and the snow treatment (i.e., natural snowmelt timing or deviation in snowmelt caused by the manipulations). For the analysis of species phenology, we additionally tested for differences in species response to experiments with advanced and delayed snowmelt (see Table 3). For the analysis of vegetation and species productivity, only data from experiments delaying snowmelt were analysed because of a lack of data. The main factors and two-way interactions were initially included in the model, but interactions with $F$ values $<2$ were subsequently pooled with the error term (Green \& Tukey 1960).

\section{Phenology}

Snowmelt is an important threshold to plant activity in habitats with a persistent snow cover. Although some 
Table 2 Characterization of meta-data sets used for the analysis of species phenology, aboveground productivity of the total vegetation and of target species in response to manipulations in snowmelt. Columns indicate the number of species, sites and years that were recorded in a snowmelt experiment. Data sets with more than one manipulation type or treatment level are specified under "additional treatments".

\begin{tabular}{|c|c|c|c|c|}
\hline & $n$ species & $n$ sites & $n$ years & Additional treatments \\
\hline \multicolumn{5}{|l|}{ Phenology } \\
\hline $\begin{array}{l}\text { Aerts et al. (2004), Aerts et al. } \\
\text { (2006) }\end{array}$ & 2 & 1 & 2 & \\
\hline Borner et al. (2008) & 2 & 1 & 1 & Two snow depth levels \\
\hline Dunne et al. (2004) & 1 & 3 & 3 & \\
\hline Saavedra (2002) & 1 & 1 & 1 & \\
\hline Walker et al. (1999) & 3 & 1 & 1 & \\
\hline Weaver \& Collins (1977) & 9 & 1 & $1-2$ & Two snow depth levels \\
\hline Wipf (2010) & 8 & 1 & 1 & Advanced and delayed \\
\hline Wipf et al. (2009) & 6 & 1 & 1 & \\
\hline \multicolumn{5}{|l|}{ Above-ground productivity } \\
\hline Knight et al. (1979) & & 2 & 1 & \\
\hline Seastedt \& Vaccaro (2001) & & 1 & 1 & \\
\hline Wahren et al. (2005) & & 1 & 1 & \\
\hline Weaver \& Collins (1977) & & 1 & 3 & Two snow depth levels \\
\hline Webber et al. (1976) & & 8 & 1 & \\
\hline \multicolumn{5}{|l|}{ Productivity of target species } \\
\hline Bell \& Bliss (1979) & 1 & 2 & 1 & \\
\hline Dorrepaal et al. (2006) & 4 & 1 & 2 & \\
\hline Knight et al. (1979) & 6 & $1-2$ & 1 & \\
\hline van der Wal et al. (2000) & 2 & 1 & 1 & \\
\hline Weaver \& Collins (1977) & 3 & 1 & 2 & Two snow depth levels \\
\hline Wipf et al. (2006) & 2 & 1 & 1 & \\
\hline
\end{tabular}

plants are known to be active under the snow (e.g., performing photosynthesis, Starr \& Oberbauer 2003; developing buds, Sørensen 1941; or growing vegetatively, Kimball \& Salisbury 1974), most species only start to show signs of phenological development after snowmelt.

After manipulations of snowmelt timing, important stages in the life cycle of plants, such as flowering, were often reached at a different time of year than usual. Often, the length of the prefloration period, i.e., the time span between snowmelt and flowering, was changed as a result of snow manipulations, showing a certain plasticity of the phenological development in response to snowmelt. Generally, the prefloration period became longer after an advanced and shorter after a delayed snowmelt (Figs. 1, 2). The slope of the regression over all species suggests that the prefloration period was shortened or prolonged by an average of $7.9 \%$ per each week that snowmelt was delayed or advanced, respectively (Fig. 1). The response in flowering phenology differed between functional groups (Table 3), with evergreen dwarf shrubs showing the strongest changes in phenology after changes in snowmelt timing (i.e., steepest slope of the regression line), followed by deciduous dwarf shrubs and forbs with weaker responses, and finally grasses with no consistent response to snow manipulations (Fig. 1).
The phenological response to snowmelt variations was not only influenced by the growth form, but also by the specific flowering timing of a plant species. In experiments with delayed snowmelt, the later in the season a plant usually flowered (i.e., the longer the prefloration period in control plots), the more it was able to accelerate its life cycle by shortening the prefloration period (Fig. 2). This pattern was especially pronounced when snowmelt was delayed very strongly (i.e., by three or more weeks; Fig. 2). In experiments with advanced snowmelt, however, the prefloration period was prolonged by about the same time span in all experiments, regardless of the timing of a species' flowering (see the regression line parallel with the $1: 1$ line in Fig. 2).

Changes in phenology can have considerable consequences for plant fitness. Advanced plant development after early snowmelt increases the risk of frost damage (Inouye 2000; Wipf et al. 2009), which can decrease plant populations directly as a result of die-off (Molau 1997), or indirectly as a result of negative effects on plant reproduction or establishment (Inouye 2008). Snowmelt-induced changes in the phenology can also affect the synchrony of species with species-specific pollinators or pests (Roy et al. 2004; Inouye 2008). Unfortunately, however, the direct or indirect links between snowmelt timing, plant phenol- 
Table 3 Effects of plant, site and snow manipulation characteristics on phenology and productivity of tundra vegetation. The responses of the three target variables were expressed as percentage change compared with control plots, and were analysed with general linear models. Details of the publications where the data was extracted from are indicated in Tables 1 and 2. Phenology was measured as the prefloration period (i.e., the duration between snowmelt and flowering). Species were divided into four functional groups: deciduous and evergreen dwarf shrubs, forbs and grasses. Natural snowmelt dates were expressed as the days of the year when snow melted in unmanipulated control plots. The deviation in snowmelt was calculated as the difference in snowmelt date between manipulated and unmanipulated plots (number of days). Snowmelt treatment indicated either advanced or delayed snowmelt, and was only included in the analysis of the phenological response, as all the data analysed for productivity responses derived from experiments with delayed snowmelt. All response variables were log-transformed prior to analysis.

\begin{tabular}{|c|c|c|c|}
\hline Effect & $d f$ & $F$ & $P$ \\
\hline \multicolumn{4}{|l|}{ Phenology } \\
\hline Functional group & 3 & 11.2 & $<0.001$ \\
\hline Prefloration period in control & 1 & 5.1 & 0.03 \\
\hline Natural snowmelt date & 1 & 0.4 & ns \\
\hline Deviation in snowmelt & 1 & 45.1 & $<0.001$ \\
\hline Snowmelt treatment & 1 & 4.5 & 0.04 \\
\hline $\begin{array}{l}\text { Prefloration period in control } \times \text { natural } \\
\text { snowmelt date }\end{array}$ & 1 & 2.0 & ns \\
\hline Error & 57 & - & - \\
\hline \multicolumn{4}{|l|}{ Productivity of total vegetation } \\
\hline Natural snowmelt date & 1 & 1.0 & ns \\
\hline Deviation in snowmelt & 1 & 0.05 & ns \\
\hline Error & 15 & - & - \\
\hline \multicolumn{4}{|l|}{ Productivity of target species } \\
\hline Functional group & 3 & 3.4 & 0.018 \\
\hline Natural snowmelt date & 1 & 0.02 & ns \\
\hline Deviation in snowmelt & 1 & 0.08 & ns \\
\hline $\begin{array}{l}\text { Natural snowmelt date } \times \text { deviation } \\
\text { in snowmelt }\end{array}$ & 1 & 4.9 & 0.033 \\
\hline Error & 33 & - & - \\
\hline
\end{tabular}

ns, not significant.

ogy and plant fitness are only rarely studied in the context of snow manipulation experiments, and too often phenology was studied as the sole response variable.

Our meta-analysis, as well as several other studies (Rixen et al. 2001; Dunne et al. 2003; Rixen et al. 2008) show that after an experimental delay of snowmelt, treatment and control plots initially show differences in the phenology, but that these differences diminish over the course of summer. This means that, depending on the timing of their life cycle, different species may be differentially affected by the snowmelt manipulations. After delayed snowmelt, the date of flowering, and thus, the time span for fruit maturation, will be changed more severely in early-flowering species than in late-flowering ones (Wipf et al. 2006). Moreover, if the snow-free period is shortened, the overlap of species' flowering periods within a community may increase (Molau 1997; Morales et al. 2005). The consequence-more species flowering at the same time-seems especially unfavourable for early-flowering species, as the number and activity of pollinators is low in early summer (Molau 1997; Wipf unpubl. data). Whether this could have negative effects for populations of early-flowering species has, to our knowledge, not been studied in detail.

\section{Growth and productivity}

The response of above-ground productivity of the whole community was analysed with 18 data sets from snow manipulation experiments with delayed snowmelt (there were not enough data from experiments with advanced snowmelt). Over all the studies, a delayed snowmelt decreased productivity by $13.1 \%$ (one-sample Student's $t$-test, $t=-2.4, d f=17, P=0.03)$. There was no clear pattern with regard to natural snowmelt date or to the level of snow manipulation (Fig. 3, Table 3). The growth responses of target species to delayed snowmelt differed between plant growth forms: grasses generally responded negatively and forbs positively (decrease in productivity by $27 \%$ and increase by 30\%, respectively; Fig. 4, Table 3), whereas deciduous and evergreen dwarf shrubs showed no clear response pattern (Fig. 4). The significant interaction between natural snowmelt and the experimentally induced delay of snowmelt (Fig. 4, Table 3) suggests that the growth response of target species was most negative with later natural snowmelt and longer delays (Fig. 4). In experiments with a moderate delay in snowmelt, however, there was no relationship between growth response and natural snowmelt timing (Fig. 4). The overall negative effect of a delay in snowmelt on community productivity may be caused by the high specialization of plant communities growing on either extreme of a snow cover gradient. The dominating species from windswept habitats with very early snowmelt, for instance, are often negatively affected by a long snow lie, such as certain lichen (Benedict 1990; Welch et al. 2005), moss (Scott et al. 2007) and sedge species (Bell \& Bliss 1979; Wahren et al. 2005). Such species probably suffer from high respiration losses when winter temperatures are increased because of deeper snow cover (Bell \& Bliss 1979; Walker et al. 1999). In habitats with naturally late snowmelt, on the other hand, plant growth may be strongly limited by the short growing season. If the snow-free season is additionally shortened, productivity is likely to be further decreased. In the short term, such processes will merely lead to a reduction in the productivity of single species, but in the longer term it may lead to a turnover in species composition (Bell \& Bliss 1979; Knight et al. 
Fig. 1 Changes in the length of the prefloration period (i.e., duration between snowmelt and flowering) in response to the extent of the snowmelt manipulations in various snowmelt manipulation experiments (Tables 1, 2). Species responses are shown for all species together (top), and then separated into functional groups. The most frequently studied species of each functional group is named and labelled with filled symbols. The rate of change in prefloration period per 10 days of change in snowmelt, calculated from the slope of the regression line, and its significance $P$ value is given for each group.

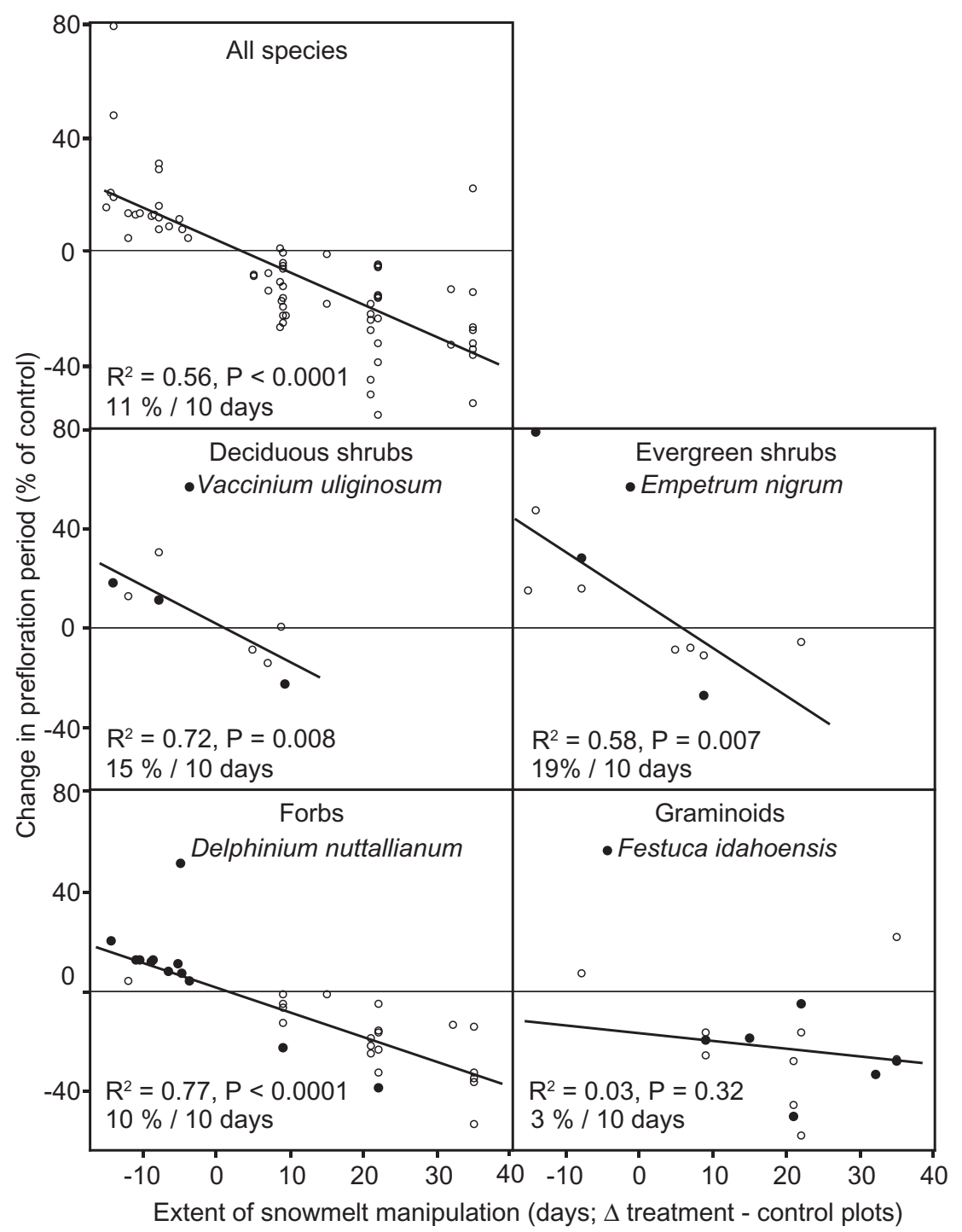

1979; Galen \& Stanton 1995; Walker et al. 1999) The few examples of a delayed snowmelt enhancing above-ground productivity were measured at sites with an intermediate snowmelt date (after 6 June in Fig. 3), where the positive effects of the additional snowpack (increased moisture and nutrients, and protection from spring frost events) might outweigh the potentially negative effects of a shortened growing season. Similarly, the productivity of target species was most negatively affected where late snowmelt and a strong experimental delay in snowmelt (>2 weeks; Fig. 4) concurred. It remains unclear whether the same patterns would also hold true when snowmelt was advanced instead of delayed, as productivity data from snow removal experiments are too scarce to be included in the meta-analysis.

\section{Vegetation composition}

The abundance of functional groups (lichens, graminoids, forbs and shrub species), and thus the vegetation composition, was considerably affected by snow addition and delayed snowmelt (see Table 4 for the response in species composition of 12 experiments with delayed snowmelt). Lichens and graminoid species (measured as proportion cover or biomass) generally decreased in abundance in response to added snow and late snowmelt, whereas forbs and dwarf shrubs remained neutral or increased in abundance (Table 4). In most studies (six out of eight), species diversity also declined as a result of delayed snowmelt, although not always significantly. 


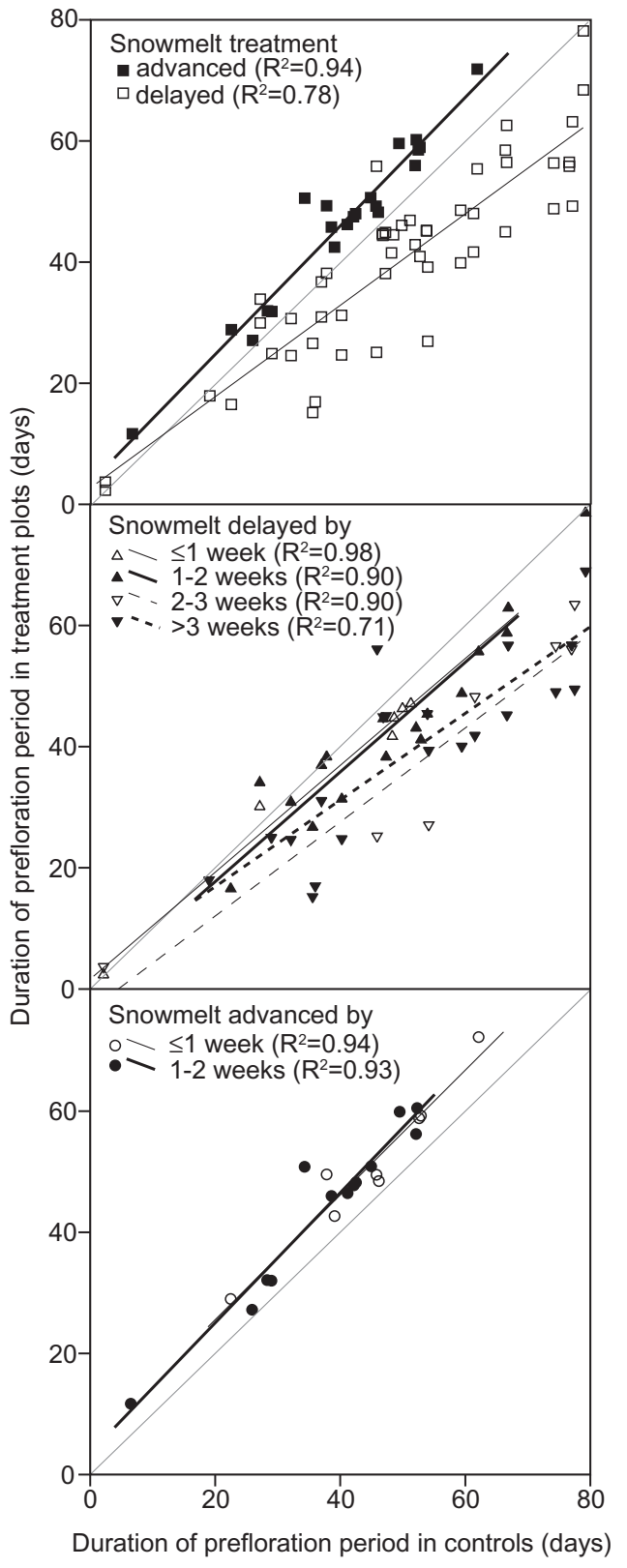

Fig. 2 The average prefloration period of a species (i.e., duration between snowmelt and flowering) in plots with manipulated snowmelt date plotted against its average prefloration period in the corresponding control plots. The top panel shows all meta-data points with advanced $(\square)$ and delayed ( $\square$ ) snowmelt (same data set as in Fig. 1). In the centre and bottom panel, experiments with delayed and advanced snowmelt are shown separately, and data points are grouped according to the duration of the delay/advance. The thin solid line represents the $1: 1$ line (i.e., same prefloration period in treatment and control plots).

The responses in vegetation composition are generally in line with the growth responses of the functional groups presented above. One explanation for the decline in graminoid species after snow addition may be the increas-

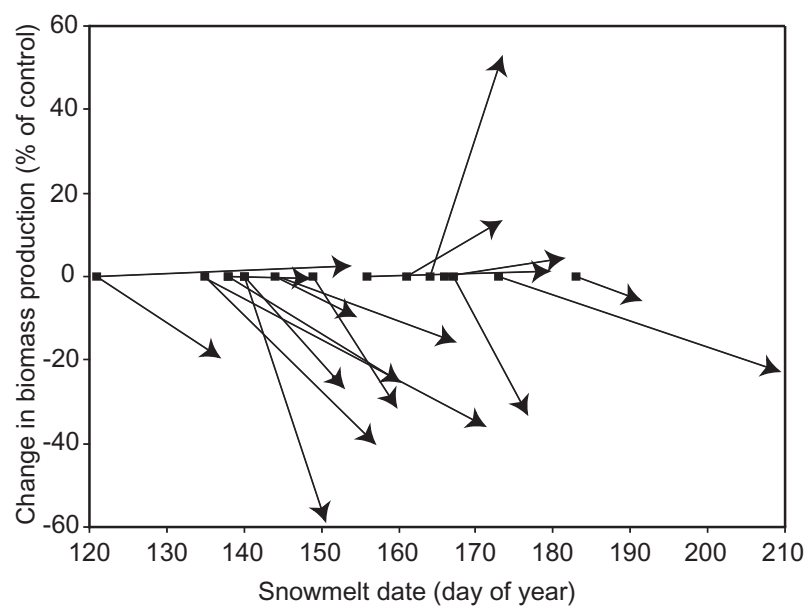

Fig. 3 Above-ground vegetation productivity in relation to snowmelt date in snow manipulation studies from Arctic and alpine ecosystems (Tables 1, 2). The productivity in plots with snow manipulation is indicated as the percentage of that in unmanipulated controls. Arrows point from mean values in control plots to means of manipulated plots in the same experiment. Day 121, 1 May; day 152, 1 June; day 182, 1 July.

ing competition by woody species in some studies (Scott \& Rouse 1995; Wahren et al. 2005). Graminoids also showed the least flexible phenology in response to snowmelt changes in our meta-analysis. Their inability to develop more rapidly after late snowmelt could account for why they were negatively affected in their productivity and, eventually, in their abundance. In several studies of the dry alpine meadows in the Rocky Mountains, one dominant graminoid species, the wind-edge species Kobresia myosuroides, showed a very negative response to increased snow (Bell \& Bliss 1977; Seastedt \& Vaccaro 2001), and thus strongly contributed to the finding that graminoid species declined. The negative reaction of lichens to delayed snowmelt could be expected given that their main habitats are locations with thin snow cover and dry summer conditions (Flock 1978). Whether it is the shortened growing season or the additional water and nutrient input that causes lichens to decline rapidly in snow-addition experiments remains unclear (Benedict 1990). Forbs, which primarily showed a positive growth response to delayed melt-out, also increased in abundance over the longer term. Many species specialized in habitats with long snow cover duration are forbs (Galen $\delta$ Stanton 1995; Björk \& Molau 2007), and these so-called snowbed species were found to benefit from prolonged snow duration in other studies as well (Wipf et al. 2005).

\section{Conclusions and wider context of snow cover changes}

The meta-analysis of snow manipulation studies can be summarized as follows. 


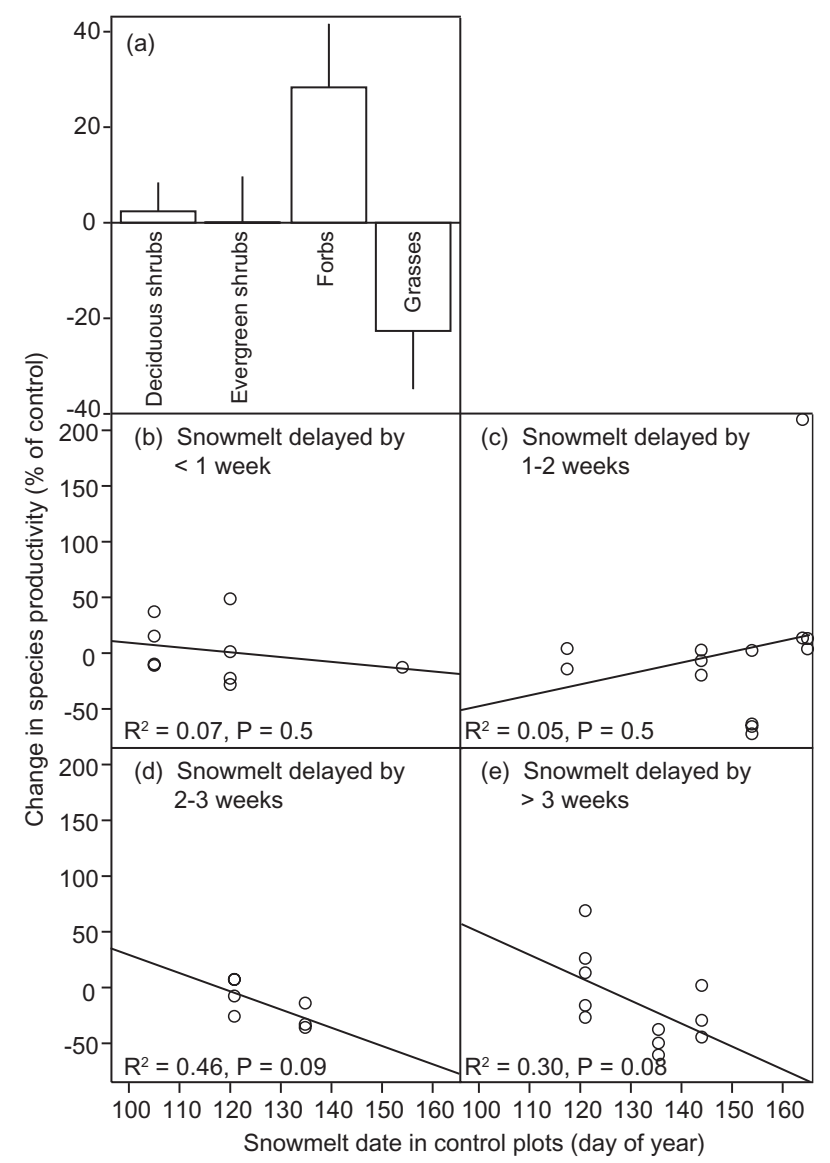

Fig. 4 Changes in productivity as a result of experimentally delayed snowmelt in (a) target species from different functional groups (means and $\mathrm{SE}$ ) and (b-e) in response to natural snowmelt date and the duration of the delay. Data were extracted from published studies as indicated in Tables 1 and 2. Day 121, 1 May; day 152, 1 June.

- Changes in the prefloration period caused by altered snowmelt timing were most pronounced in earlyflowering species. The more that experimental and natural snowmelt differed, the stronger was the change in the prefloration period.

- Overall community productivity was decreased by experimentally delayed snowmelt, but plant functional groups differed in their response: forbs were enhanced in growth by later snowmelt, but grasses declined.

- Delayed snowmelt caused an overall decline in diversity that was mostly caused by a decline in abundance of lichens and graminoids.

The snow manipulation experiments analysed in this review have demonstrated that changes in snow cover characteristics can considerably influence plant growth and performance. In addition to experiments, observational studies and studies in soil sciences have shown considerable impacts of snow cover changes on Arctic and alpine ecosystems. The ecosystem responses to changes in snow cover can be immediate and of a similar magnitude as the responses to other crucial climate factors, such as temperature, summer precipitation and $\mathrm{CO}_{2}$ concentration. Changes in winter snow cover can show impacts that are still visible during the following growing season, thus influencing processes mainly attributed to summer. For instance, the insulation by the winter snowpack can control microbial activity and decomposition rates, and thus the nutrient availability to plants the following summer (Williams et al. 1998; Schimel et al. 2004; Rixen et al. 2008). Furthermore, altered winter snow cover can affect growing season soil moisture, which interacts with the effects of summer temperatures, especially in regions with low summer precipitation (Walker et al. 1999; Chimner \& Welker 2005). In fact, tundra biomass productivity (measured as maximum normalized difference vegetation index in summer) was enhanced after winters with deep snow cover and late snowmelt in Siberia, regardless of the summer climate, which is attributed to higher nutrient and water availability (Grippa et al. 2005). Early snowmelt followed by cold spring temperatures, on the other hand, reduced tundra productivity (Stow et al. 2004) and boreal tree growth (Kirdyanov et al. 2003). In ecosystems where the growing season length is extremely short, such as in snowbeds, early snowmelt usually fosters biomass production (Walker et al. 1994; Björk \& Molau 2007).

\section{Future research}

Campbell et al. (2005) raised a number of ideas on how winter ecological processes should best be investigated. In particular, they emphasize the need for standardized protocols for winter measurements, and integrative approaches over different levels of the ecosystems and different spatial scales. In addition to these suggestions, we would like to raise the following points that apply particularly to snow ecology experiments.

Long-term studies simulating realistic snow cover scenarios for the region or the ecosystem in question are sparse. This especially applies to the advancement of snowmelt, which is a realistic scenario for many Arctic and alpine areas. Thus, further such experiments with a long-term goal would be highly desirable.

In future experiments, the interdisciplinary approach should be further strengthened. Responses on different levels of the ecosystem (such as biogeochemistry, plant performance, vegetation composition and herbivores), and the interactions between these aspects of the ecosystem, should be studied and quantified in the same experiment to gain as much information and predictive power as possible. This is especially important because 
Table 4 Qualitative responses of species diversity and vegetation composition (abundance of plant functional groups) to experimental changes in snowmelt timing. The results summarized here were presented as significant changes in the vegetation structure, or were listed in tables and figures describing the species composition. Empty cells mean that a functional group was not present or that no data were presented.

\begin{tabular}{|c|c|c|c|c|c|c|c|c|c|c|}
\hline Publication & $\begin{array}{l}\text { Parameter } \\
\text { measured }\end{array}$ & $\begin{array}{l}\text { Duration of } \\
\text { experiment } \\
\text { (years) }\end{array}$ & $\begin{array}{l}\text { Natural } \\
\text { snowmelt date } \\
\text { (day of year) }\end{array}$ & $\begin{array}{l}\text { Deviation } \\
\text { from natural } \\
\text { snowmelt (days) }\end{array}$ & $\begin{array}{l}\text { Species } \\
\text { diversity }\end{array}$ & Lichens & $\begin{array}{l}\text { Woody } \\
\text { species }\end{array}$ & Graminoids & Forbs & Mosses \\
\hline Knight et al. (1979) & Biomass & 5 & 164 & +9 & - & & & + & $=$ & - \\
\hline Knight et al. (1979) & Biomass & 5 & 154 & +8 & - & & & + & - & \\
\hline Scott \& Rouse (1995) & Cover & 13 & NA & +7 & - & - & + & - & & \\
\hline Seastedt \& Vaccaro (2001) & Cover & 4 & 173 & +35 & - & - & $=$ & $=$ & $=$ & $=$ \\
\hline Seastedt \& Vaccaro (2001) & $n$ species & 4 & 173 & +35 & - & & + & - & + & \\
\hline Smith et al. (1995) & Cover & 32 & NA & $+\mathrm{NA}$ & + & - & & & & \\
\hline Wahren et al. (2005) & Cover & 8 & 135 & +31 & - & - & + & & & \\
\hline Wahren et al. (2005) & Cover & 8 & 145 & +21 & + & - & - & - & & + \\
\hline Weaver \& Collins (1977) & Cover & 6 & 135 & +9 & & & & - & + & \\
\hline Weaver \& Collins (1977) & Cover & 6 & 135 & +20 & & & & - & + & \\
\hline Welch et al. (2005) & Cover & 12 & NA & +6 & & - & & & & \\
\hline Wipf (2006) & Cover & 2 & 150 & -8 & & $=$ & - & $=$ & - & \\
\hline
\end{tabular}

well-designed, large-scale snow manipulation experiments are very difficult and laborious to accomplish.

Only a few studies simulate episodic extreme events in winter and spring, such as midwinter thawing or spring frosts, although such events may have even larger impacts on ecosystems than slow and gradual changes in the winter climate. Specific experimental approaches, as well as long-term data series combining ecosystem and winter climate parameters, are needed to study ecosystem responses to gradual changes as well as to extreme events. Long-term studies require reliable measurements of winter climate data such as winter precipitation, snow depth, snowmelt timing and temperatures.

Apart from winter conditions, the growing conditions in spring, which for Arctic and alpine plants starts with the melting of the snow cover, can also have considerable effects on plant fitness and ecosystem processes (Jonas et al. 2008). Therefore, winter and spring climate scenarios should be taken into account and combined in future climate change experiments.

There is ample evidence that winter climate change has a great potential to modify ecosystem processes in Arctic an alpine ecosystems. Experimental studies of snow cover changes can improve our understanding of ecosystem changes that have been observed in recent years, such as the increase in shrub cover in the Arctic (Sturm et al. 2005; Tape et al. 2006). Compared with summer processes, however, there are still many open questions requiring further investigation in the field of Arctic and alpine winter ecology.

\section{Acknowledgements}

We would like to thank all of the winter ecology researchers who have shared their knowledge and experience on snow experiments with us over the years. Moreover, we thank Bernhard Schmid and Christa Mulder for helpful discussions on the analyses, and Isla Myers-Smith and further anonymous reviewers for constructive suggestions that substantially improved the manuscript.

\section{References}

Aerts R., Cornelissen J.H.C. \& Dorrepaal E. 2006. Plant performance in a warmer world: general responses of plants from cold, northern biomes and the importance of winter and spring events. Plant Ecology 182, 65-77.

Aerts R., Cornelissen J.H.C., Dorrepaal E., van Logtestijn R.S.P. \& Callaghan T.V. 2004. Effects of experimentally imposed climate scenarios on flowering phenology and flower production of subarctic bog species. Global Change Biology 10, 1599-1609.

Bell K.L. \& Bliss L.C. 1977. Overwinter phenology of plants in a polar semi-desert. Arctic 30, 118-121.

Bell K.L. \& Bliss L.C. 1979. Autecology of Kobresia bellardii-why winter snow accumulation limits local distribution. Ecological Monographs 49, 377-402.

Benedict J.B. 1990. Lichen mortality due to late-lying snow-results of a transplant study. Arctic and Alpine Research 22, 81-89.

Beniston M. 1997. Variations of snowdepth and duration in the Swiss Alps over the last 50 years: links to changes in large-scale climatic forcings. Climatic Change 36, 281-300.

Björk R.G. \& Molau U. 2007. Ecology of alpine snowbeds and the impact of global change. Arctic, Antarctic, and Alpine Research 39, 34-43.

Bokhorst S., Bjerke J.W., Bowles F.W., Melillo J., Callaghan T.V. \& Phoenix G.K. 2008. Impacts of extreme winter warming in the sub-Arctic: growing season responses of 
dwarf shrub heathland. Global Change Biology 14, 2603-2612.

Borner A., Kielland K. \& Walker M. 2008. Effects of simulated climate change on plant phenology and nitrogen mineralization in Alaskan Arctic tundra. Arctic, Antarctic, and Alpine Research 40, 27-38.

Boutin R. \& Robitaille G. 1995. Increased soil nitrate losses under mature sugar maple trees affected by experimentally-induced deep frost. Canadian Journal of Forest Research 25, 588-602.

Brown R.D. 2000. Northern Hemisphere snow cover variability and change, 1915-97. Journal of Climate 13, 2339-2355.

Buus-Hinkler J., Hansen B.U., Tamstorf M.P. \& Pedersen S.B. 2006. Snow-vegetation relations in a High Arctic ecosystem: inter-annual variability inferred from new monitoring and modeling concepts. Remote Sensing of Environment 105, 237-247.

Campbell J.L., Mitchell M.J., Groffman P.M., Christenson L.M. \& Hardy J.P. 2005. Winter in northeastern North America: an often overlooked but critical period for ecological processes. Frontiers in Ecology and the Environment 3, 314-322.

Chapin F.S., Bret-Harte M.S., Hobbie S.E. \& Zhong H.L. 1994. Plant functional types as predictors of transient responses of Arctic vegetation to global change. Journal of Vegetation Science 7, 347-358.

Chimner R.A. \& Welker J.M. 2005. Ecosystem respiration responses to experimental manipulations of winter and summer precipitation in a mixed grass Prairie, WY, USA. Biogeochemistry 73, 257-270.

Dickinson K.J.M., Kelly D., Mark A.F., Wells G. \& Clayton R. 2007. What limits a rare alpine plant species? Comparative demography of three endemic species of Myosotis (Boraginaceae). Austral Ecology 32, 155-168.

Dormann C.F. \& Woodin S.J. 2002. Climate change in the Arctic: using plant functional types in a meta-analysis of field experiments. Functional Ecology 16, 4-17.

Dorrepaal E., Aerts R., Cornelissen J.H.C., Callaghan T.V. \& van Logtestijn R.S.P. 2003. Summer warming and increased winter snow cover affect Sphagnum fuscum growth, structure and production in a sub-Arctic bog. Global Change Biology 10, 93-104.

Dorrepaal E., Aerts R., Cornelissen J.H.C., van Logtestijn R.S.P. \& Callaghan T.V. 2006. Sphagnum modifies climate-change impacts on subarctic vascular bog plants. Functional Ecology 20, 31-41.

Dunne J.A., Harte J. \& Taylor K.J. 2003. Subalpine meadow flowering phenology responses to climate change: integrating experimental and gradient methods. Ecological Monographs 73, 69-86.

Dunne J.A., Saleska S.R., Fischer M.L. \& Harte J. 2004. Integrating experimental and gradient methods in ecological climate change research. Ecology 85, 904-916.

Edmonds T., Lunt I.D., Roshier D.A. \& Louis J. 2006. Annual variation in the distribution of summer snowdrifts in the
Kosciuszko alpine area, Australia, and its effect on the composition and structure of alpine vegetation. Austral Ecology 31, 837-848.

Fahnestock J.T., Povirk K.L. \& Welker J.M. 2000. Ecological significance of litter redistribution by wind and snow in Arctic landscapes. Ecography 23, 623-631.

Flock J.W. 1978. Lichen-bryophyte distribution along a snow-cover-soil-moisture gradient, Niwot Ridge, Colorado. Arctic and Alpine Research 10, 31-47.

Frei A., Robinson D.A. \& Hughes M.G. 1999. North American snow extent: 1900-1994. International Journal of Climatology 19, 1517-1534.

Galen C. \& Stanton M.L. 1993. Short-term responses of alpine buttercups to experimental manipulations of growing-season length. Ecology 74, 1052-1058.

Galen C. \& Stanton M.L. 1995. Responses of snowbed plant-species to changes in growing-season length. Ecology 76, 1546-1557.

Galen C. \& Stanton M.L. 1999. Seedling establishment in alpine buttercups under experimental manipulations of growing-season length. Ecology 80, 2033-2044.

Green B.F.J. \& Tukey J.W. 1960. Complex analyses of variance: general problems. Psychometrika 25, 127-152.

Grippa M., Kergoat L., Le Toan T., Mognard N.M., Delbart N., L'Hermitte J. \& Vicente-Serrano S.M. 2005. The impact of snow depth and snowmelt on the vegetation variability over central Siberia. Geophysical Research Letters 32, L21412, doi: 10.1029/2005GL024286.

Groffman P.M., Driscoll C.T., Fahey T.J., Hardy J.P., Fitzhugh R.D. \& Tierney G.L. 2001. Colder soils in a warmer world: a snow manipulation study in a northern hardwood forest ecosystem. Biogeochemistry 56, 135-150.

Groffman P.M., Hardy J.P., Nolan S., Fitzhugh R.D., Driscoll C.T. \& Fahey T.J. 1999. Snow depth, soil frost and nutrient loss in a northern hardwood forest. Hydrological Processes 13, 2275-2286.

Harte J., Torn M.S., Chang F.-R., Feifarek B., Kinzig A.P., Shaw R. \& Shen K. 1995. Global warming and soil microclimate: results from a meadow-warming experiment. Ecological Applications 5, 132-150.

Henry H.A.L. 2008. Climate change and soil freezing dynamics: historical trends and projected changes. Climatic Change 87, 421-434.

Inouye D.W. 2000. The ecological and evolutionary significance of frost in the context of climate change. Ecology Letters 3, 457-463.

Inouye D.W. 2008. Effects of climate change on phenology, frost damage, and floral abundance of montane wildflowers. Ecology 89, 353-362.

Jonas T., Rixen C., Sturm M. \& Stoeckli V. 2008. How alpine plant growth is linked to snow cover and climate variability. Journal of Geophysical Research-Biogeosciences 113, G03013, doi: 10.1029/2007JG000680.

Kimball S.L. \& Salisbury F.B. 1974. Plant development under snow. Botanical Gazette 135, 147-149.

Kirdyanov A., Hughes M., Vaganov E., Schweingruber F. \& Silkin P. 2003. The importance of early summer 
temperature and date of snow melt for tree growth in the Siberian subarctic. Trees-Structure and Function 17, 61-69.

Knight D.H., Weaver S.W., Starr C.R. \& Romme W.H. 1979. Differential response of subalpine meadow vegetation to snow augmentation. Journal of Range Management 32, 356-359.

Lapp S., Byrne J., Townshend I. \& Kienzle S. 2005. Climate warming impacts on snowpack accumulation in an alpine watershed. International Journal of Climatology 25, 521-536.

La Puma I.P., Philippi T.E. \& Oberbauer S.F. 2007. Relating NDVI to ecosystem $\mathrm{CO}_{2}$ exchange patterns in response to season length and soil warming manipulations in Arctic Alaska. Remote Sensing of Environment 109, 225236.

Laternser M. \& Schneebeli M. 2003. Long-term snow climate trends of the Swiss Alps (1931-99). Journal of Climatology 23, 733-750.

Marty C. 2008. Regime shift of snow days in Switzerland. Geophysical Research Letters 35, L12501, doi: 10.1029/ $2008 \mathrm{gl033998.}$

Molau U. 1997. Phenology and reproductive success in Arctic plants: susceptibility to climate change. In W.C. Oechel et al. (eds.): Global change and Arctic terrestrial ecosystems. Pp. 153-170. New York: Springer.

Morales M.A., Dodge G.J. \& Inouye D.W. 2005. A phenological mid-domain effect in flowering diversity. Oecologia 142, 83-89.

Mote P.W., Hamlet A.F., Clark M.P. \& Lettenmaier D.P. 2005. Declining mountain snowpack in western North America. Bulletin of the American Meteorological Society 86, 39-49.

OcCC Consortium 2007. Klimaänderung und die Schweiz 2050. (Climate change and Switzerland 2050.) Bern: Advisory Body on Climate Change/Proclim-Forum for Climate and Global Change.

Rikiishi K., Hashiya E. \& Imai M. 2004. Linear trends of the length of snow-cover season in the Northern Hemisphere as observed by the satellites in the period 1972-2000. Annals of Glaciology 38, 229-237.

Rixen C., Freppaz M., Stoeckli V., Huovinen C., Huovinen K. \& Wipf S. 2008. Altered snow density and chemistry change soil nitrogen mineralization and plant growth. Arctic, Antarctic, and Alpine Research 40, 568-575.

Rixen C., Stoeckli V., Huovinen C. \& Huovinen K. 2001. The phenology of four subalpine herbs in relation to snow cover characteristics. In A.J. Dolman et al. (eds.): Soil-vegetation-atmosphere transfer schemes and large-scale hydrological models. Proceedings of an international symposium (Symposium S5) held during the Sixth Scientific Assembly of the International Association of Hydrological Sciences (IAHS) at Maastricht, the Netherlands, from 18 to 27 July 2001. Pp. 359-362. Wallingford, UK: International Association of Hydrological Sciences.

Roy B.A., Güsewell S. \& Harte J. 2004. Response of plant pathogens and herbivores to a warming experiment. Ecology 85, 2570-2581.

Saavedra F. 2002. Testing climate change predictions with the subalpine species Delphinium nuttallianum. In S.H.
Schneider \& T.L. Root (eds.): Wildlife responses to climate change. Pp. 201-249. Washington, DC: Island Press.

Saha S.K., Rinke A. \& Dethloff K. 2006. Future winter extreme temperature and precipitation events in the Arctic. Geophysical Research Letters 33, L15818, doi: 10.1029/ 2006GL026451.

Scherrer S.C., Appenzeller C. \& Laternser M. 2004. Trends in Swiss alpine snow days: the role of local- and large-scale climate variability. Geophysical Research Letters 31, L13215, doi: 10.1029/2004GL020255.

Schimel J.P., Bilbrough C.J. \& Welker J.M. 2004. Increased snow depth affects microbial activity and nitrogen mineralization in two Arctic tundra communities. Soil Biology $\theta$ Biochemistry 36, 217-227.

Scott D., Welch D., van der Wal R. \& Elston D.A. 2007. Response of the moss Racomitrium lanuginosum to changes in sheep grazing and snow-lie due to a snow-fence. Applied Vegetation Science 10, 229-238.

Scott P.A. \& Rouse W.R. 1995. Impacts of increased winter snow cover on upland tundra vegetation-a case example. Climate Research 5, 25-30.

Seastedt T.R. \& Vaccaro L. 2001. Plant species richness, productivity, and nitrogen and phosphorus limitations across a snowpack gradient in alpine tundra, Colorado, USA. Arctic, Antarctic, and Alpine Research 33, 100-106.

Serreze M.C., Walsh J.E., Chapin F.S., Osterkamp T., Dyurgerov M., Romanovsky V., Oechel W.C., Morison J., Zhang T. \& Barry R.G. 2000. Observational evidence of recent change in the northern high-latitude environment. Climatic Change 46, 159-207.

Siffi C. 2007. Effetto della variazione della copertura nevosa in una brughiera soprasilvatica dell'Appennino Settentrionale. (Effect of snow cover variations on a subalpine heath ecosystem in the Northern Appennine Mountains.) PhD thesis, University of Ferrara.

Smith B., Mark A.F. \& Wilson J.B. 1995. A functional analysis of New Zealand alpine vegetation: variation in canopy roughness and functional diversity in response to an experimental wind barrier. Functional Ecology 9, 904-912. Solomon S., Qin D., Manning M., Chen Z., Marquis M., Averyt K.B., Tignor M. \& Miller H.L. Jr. (eds.) 2007. Climate change 2007. The physical science basis. Contribution of Working Group I to the fourth assessment report of the Intergovernmental Panel on Climate Change. Cambridge: Cambridge University Press.

Sørensen T. 1941. Temperature relations and phenology of the northeast greenland flowering plants. Copenhagenn: C.A. Reitzels Forlag.

Starr C.R. \& Oberbauer S.F. 2003. Photosynthesis of Arctic evergreens under snow: implications for tundra ecosystem carbon balance. Ecology 84, 1415-1428.

Starr G., Oberbauer S. \& Ahlquist L. 2008. The photosynthetic response of Alaskan tundra plants to increased season length and soil warming. Arctic, Antarctic, and Alpine Research 40, 181-191.

Starr G., Oberbauer S.F. \& Pop E.W. 2000. Effects of lengthened growing season and soil warming on the 
phenology and physiology of Polygonum bistorta. Global Change Biology 6, 357-369.

Stinson K.A. 2004. Natural selection favors rapid reproductive phenology in Potentilla pulcherrima (Rosaceae) at opposite ends of a subalpine snowmelt gradient. American Journal of Botany 91, 531-539.

Stinson K.A. 2005. Effects of snowmelt timing and neighbor density on the altitudinal distribution of Potentilla diversifolia in western Colorado, USA. Arctic, Antarctic, and Alpine Research 37, 379-386.

Stow D.A., Hope A., McGuire D., Verbyla D., Gamon J., Huemmrich F., Houston S., Racine C., Sturm M., Tape K., Hinzman L., Yoshikawa K., Tweedie C., Noyle B., Silapaswan C., Douglas D., Griffith B., Jia G., Epstein H., Walker D., Daeschner S., Petersen A., Zhou L.M. \& Myneni R. 2004. Remote sensing of vegetation and land-cover change in Arctic tundra ecosystems. Remote Sensing of Environment 89, 281-308.

Sturges D.L. 1989. Response of mountain big sagebrush to induced snow accumulation. Journal of Applied Ecology 26, 1035-1041.

Sturm M., Holmgren J., Konig M. \& Morris K. 1997. The thermal conductivity of seasonal snow. Journal of Glaciology 43, 26-41.

Sturm M., Schimel J., Michaelson G., Welker J.M., Oberbauer S.F., Liston G.E., Fahnestock J. \& Romanovsky V.E. 2005. Winter biological processes could help convert Arctic tundra to shrubland. Bioscience 55, 17-26.

Symon C., Arris L. \& Heal B. (eds.) 2005. Arctic climate impact assessment. Cambridge: Cambridge University Press.

Tape K., Sturm M. \& Racine C. 2006. The evidence for shrub expansion in northern Alaska and the pan-Arctic. Global Change Biology 12, 686-702.

van der Wal R., Madan N., van Lieshout S., Dormann C., Langvatn R. \& Albon S.D. 2000. Trading forage quality for quantity? Plant phenology and patch choice by Svalbard reindeer. Oecologia 123, 108-115.

Wahren C.-H.A., Walker M.D. \& Bret-Harte M.S. 2005. Vegetation responses in Alaskan Arctic tundra after 8 years of a summer warming and winter snow manipulation experiment. Global Change Biology 11, 537-552.

Walker D.A., Billings W.D. \& De Molenaar J.G. 2001. Snow-vegetation interactions in tundra environments. In H.G. Jones et al. (eds.): Snow ecology: an interdisciplinary examination of snow-covered ecosystems. Pp. 266-324. Cambridge: Cambridge University Press.

Walker M.D., Walker D.A., Welker J.M., Arft A.M., Bardsley T., Brooks P.D., Fahnestock J.T., Jones M.H., Losleben M., Parsons A.N., Seastedt T.R. \& Turner P.L. 1999. Long-term experimental manipulation of winter snow regime and summer temperature in Arctic and alpine tundra.

Hydrological Processes 13, 2315-2330.

Walker M.D., Webber P.J., Arnold E.H. \& Ebert May D. 1994. Effects of interannual climate variation on aboveground phytomass in alpine vegetation. Ecology 75, 393-408.

Walsh N.E., McCabe T.R., Welker J.M. \& Parsons A.N. 1997. Experimental manipulations of snow-depth: effects on nutrient content of caribou forage. Global Change Biology 3, 158-164.

Weaver T. \& Collins D. 1977. Possible effects of weather-modification (increased snowpack) on Festuca idahoensis meadows. Journal of Range Management 30, 451-456.

Webber P.J., Emerick J.C., May D.C.E. \& Komarkova V. 1976. The impact of increased snowfall on alpine vegetation. In H.W. Steinhoff \& J.D. Ives (eds.): Ecological impacts of snowpack augmentation in the San Juan Mountains, Colorado. Final report, San Juan Ecology Project. Pp. 201-259. Fort Collins: Colorado State University Publications.

Welch D., Scott D. \& Thompson D.B.A. 2005. Changes in the composition of Carex bigelowi-Racomitrium lanuginosum moss heath on Glas Maol, Scotland, in response to sheep grazing and snow fencing. Biological Conservation 122, 621-631.

Welker J.M., Fahnestock J.T., Sullivan P.F. \& Chimner R.A. 2005. Leaf mineral nutrition of Arctic plants in response to warming and deeper snow in northern Alaska. Oikos 109, 167-177.

Williams M.W., Brooks P.D. \& Seastedt T. 1998. Nitrogen and carbon soil dynamics in response to climate change in a high-elevation ecosystem in the Rocky Mountains, USA. Arctic and Alpine Research 30, 26-30.

Wipf S. 2006. Winter climate change in tundra ecosystems: the importance of snow cover. PhD thesis, University of Zurich.

Wipf S. 2010. Phenology, growth, and fecundity of eight subarctic tundra species in response to snowmelt manipulations. Plant Ecology 207, 53-66.

Wipf S., Rixen C., Fischer M., Schmid B. \& Stoeckli V. 2005. Effects of ski piste preparation on alpine vegetation. Journal of Applied Ecology 42, 306-316.

Wipf S., Rixen C. \& Mulder C.P.H. 2006. Advanced snowmelt causes shift towards positive neighbour interactions in a subarctic tundra community. Global Change Biology 12, 1496-1506.

Wipf S., Stoeckli V. \& Bebi P. 2009. Winter climate change in alpine tundra: plant responses to changes in snow depth and snowmelt timing. Climatic Change 94, 105-121. 